\title{
Evaluasi Pelaksanaan Program Upaya Kesehatan Jiwa di Puskesmas Bandarharjo Kota Semarang Tahun 2018
}

\author{
Resqy Rhaudatul Jannah \\ Universitas Islam Negeri Alauddin Makassar \\ Email : khikyri26@gmail.com
}

\section{Pendahuluan}

Kesehatan jiwa merupakan suatu keadaan individu yang secara mandiri menyadari kemampuannya dan mampu mengembangkan kemampuan tersebut baik secara fisik, mental, spiritual juga sosial; sanggup mengatasi tekanan sehingga individu tersebut dapat bekerja secara produktif serta memberikan kontribusi bagi masyarakat sekitar. Permasalahan dalam bidang kesehatan jiwa hingga kini masih menjadi beban ekonomi terbesar di seluruh dunia, jika dibandingkan dengan masalah kesehatan lain. Hal ini dikarenakan permasalahan kesehatan jiwa telah menelan dana sebanyak US $\$ 2,5$ triliun pada tahun 2010, yang diperkirakan akan terus bertambah menjadi US $\$ 6$ triliun pada tahun 2030.1 Kesehatan jiwa menjadi beban ekonomi dunia dengan menghabiskan 2/3 dana akibat hilangnya pekerjaan dan disabilitas.

1. Analisis Berbasis Bukti (Evidence Based Analysis)

Berdasarkan penelitian yang dilakukan oleh Hermiati dan Harahap (2018) menyebutkan bahwa faktor pencetus terjadinya skizofrenia dapat dipengaruhi oleh emotional turbulent families, stressful life events, diskriminasi, dan kemiskinan. Lingkungan emosional yang tidak stabil dapat juga dianggap mempunyai risiko yang besar terhadap perkembangan skizofrenia. Berdasarkan latar belakang tersebut, perlu dilakukan penelitian mengenai evaluasi pelaksanaan program upaya kesehatan jiwa di Puskesmas Bandarharjo Kota Semarang.

2. Analisis Kekuatan Medan (Field Force Analysis)

- Evaluasi Input

a) Ketersediaan tenaga Upaya Kesehatan Jiwa dapat dikategorikan cukup.

b) Sumber dana yang digunakan untuk program Upaya Kesehatan Jiwa sudah cukup dan berasal dari BOK.

c) Sarana dan bahan yang sudah tersedia baik secara kuantitas maupun secara kualitas sudah mencukupi kebutuhan.

d) Seluruh kegiatan program Upaya Kesehatan Jiwa belum memiliki SOP dan belum ada pembuatan berita acara pada setiap tahap pelaksanaan program Upaya Kesehatan Jiwa.

e) Belum terdapat penjadwalan program Upaya Kesehatan Jiwa secara khusus. Perencanaan dalam pelaksanaan program Upaya Kesehatan Jiwa di Puskesmas Bandarharjo dilaksanakan bersamaan dengan evaluasi kinerja program yang dilakukan per tahun.

- Evaluasi Process

a) Pelaksanaan deteksi dini rutin dilakukan oleh dokter dan perawat setiap kali melakukan pemeriksaan.Kegiatan ini menemui hambatan yakni Puskesmas masih belum bersikap proaktif.

b) Penegakan diagnosis oleh Puskesmas secara keseluruhan sudah dilakukan dengan baik dan tidak ditemui kendala dalam pelaksanaannya. 
c) Pada penatalaksaan awal ditemukan hambatan yakni terbatasnya ketersediaan stok obat tertentu yang mengakibatkan terhambatnya pendistribusian obat ke masyarakat.

d) Pada rujukan balik kasus gangguan jiwa, ditemukan hambatan yakni kesulitan dalam sistem rujukan berjenjang akibat dari aturan BPJS terbaru terkait rujukan balik yang masih perlu untuk dikaji ulang.

e) Pelaksanaan kegiatan penyuluhan kesehatan jiwa oleh Puskesmas masih belum optimal dikarenakan sulitnya mengumpulkan semua peserta penyuluhan dalam satu waktu yang bersamaan.

- Evaluasi Output

Evaluasi keluaran (output), dari 2 indikator program Upaya Kesehatan Jiwa (jumlah kunjungan gangguan jiwa dan jumlah ODGJ berat yang mendapatkan pelayanan kesehatan jiwa sesuai standar) terdapat 1 indikator yang belum mencapai target yaitu dan jumlah ODGJ berat yang mendapatkan pelayanan kesehatan jiwa sesuai standar di Puskesmas Bandarharjo sebesar 94,7\% dengan target sebesar $100 \%$ dikarenakan pengelolaan rujukan balik kasus gangguan jiwa yang belum optimal.

3. Analisis Penguatan Kelembagaan (Institutional Strenghtening Analysis)

- Variabel Input

a) Tenaga

Tenaga atau sumber daya manusia yang terlibat di dalam program Upaya Kesehatan Jiwa di puskesmas berjumlah 5 orang, yaitu kepala pemegang program, dokter, perawat, bidan, promkes, dan kader kesehatan. Kepala pemegang program bertugas untuk mengoordinir pelaksanaan program. Dokter bertugas untuk anamnesa, melakukan pemeriksaan fisik, mengobati (kuratif), juga melakukan rujukan. Perawat mempunyai tugas untuk membantu dokter dalam melakukan anamnesa. Bidan bertugas untuk menangani secara spesifik bagian KIA yakni ibu hamil yang mengalami gejala depresi post partum setelah persalinan juga anak kecil usia di bawah 7 tahun yang mengalami waham/gejala gangguan jiwa. Promkes mempunyai tugas dalam melakukan penyuluhan kesehatan jiwa. Sementara itu, kader juga ikut terlibat secara tidak langsung di dalam program kesehatan jiwa. Kader mempunyai tugas untuk membantu pencatatan dan pelaporan di wilayah. Jumlah SDM yang terlibat dalam program Upaya Kesehatan Jiwa Puskesmas sudah cukup, karena untuk pengobatan lebih banyak merujuk.

b) Dana

Dana yang diterima puskesmas untuk menjalankan program Upaya Kesehatan Jiwa berasal dari BOK (Biaya Operasional Kesehatan) dari pusat. Dana yang sudah diterima oleh Puskesmas harus dicukupkan dalam menjalankan program karena sudah diplot. Dana ini digunakan untuk memenuhi berbagai kebutuhan Puskesmas dalam menjalankan program, seperti untuk membeli barang saat penyuluhan (snack dan ATK), biaya perjalanan untuk pelatihan kader ke luar, dan biaya operasional Puskesmas.

c) Sarana

Sarana pendukung program Upaya Kesehatan Jiwa juga harus dilihat dari segi kualitas dan kuantitasnya untuk kelancaran dan keberhasilan dalam pelaksanaannya. Dari segi kuantitas sarana pendukung program Upaya Kesehatan Jiwa di Puskesmas sudah mencukupi kebutuhan, karena apabila petugas memerlukan sarana tambahan (misalnya ambulans) dapat langsung menelepon Pemkot agar disediakan. 
d) Metode

Program Upaya Kesehatan Jiwa yang ada di Puskesmas Bandarharjo belum memiliki SOP. Terdapat informasi yang berbeda dari salah satu dokter juga perawat terkait SOP program Upaya Kesehatan Jiwa yang seharusnya ada mengikuti akreditasi Puskesmas yang sudah dilaksanakan sebelumnya. Dalam pelaksanaan suatu program, diperlukan bukti terlaksananya suatu program berupa laporan.

e) Waktu

Perencanaan dalam pelaksanaan program Upaya Kesehatan Jiwa di Puskesmas Bandarharjo dilaksanakan bersamaan dengan evaluasi kinerja program yang dilakukan per tahun, namun perencanaan tersebut tidak memuat jadwal/waktu pelaksanaan secara khusus. Oleh karena itu, pelaksanaan program Upaya Kesehatan Jiwa di Puskesmas Bandarharjo tidak dapat dilihat keberjalannya apakah sudah sesuai dengan jadwal yang sudah direncanakan. Terdapat penjadwalan kegiatan program Upaya Kesehatan Jiwa di wilayah RW/kelurahan yakni berupa rapat kader.

- Variabel Process

a) Melaksanakan Deteksi Dini

Pelaksanaan deteksi dini dilakukan oleh petugas kesehatan kepada pasien dengan gangguan jiwa. Deteksi dini dilaksanakan setiap kali melakukan pemeriksaan. Selain itu, deteksi dini juga dapat dilakukan di luar Puskesmas, semisal melalui penjaringan di sekolah. Dalam melaksanakan kegiatan deteksi dini terdapat faktor-faktor yang mendukung yakni keterusterangan pihak keluarga pasien, kesadaran dan kemauan dari pihak pasien untuk datang ke Puskesmas dan mengobati penyakitnya.

b) Penegakan Diagnosis

Penegakan diagnosis merupakan tahapan yang sejalan dengan deteksi dini, yakni mengidentifikasi gangguan jiwa pada pasien berdasarkan kriteria tertentu pada saat dilakukan pemeriksaan. Penegakan diagnosis dilakukan oleh petugas kesehatan kepada pasien dengan gangguan jiwa. Penegakan diagnosis dilaksanakan setiap kali melakukan pemeriksaan. Penegakan diagnosis dilakukan melalui penegakan anamnesa yakni $70 \%$ dari penegakan anamnesa sebagai bentuk pemeriksaan penunjang apabila terjadi infeksi, karena laboratorium yang ada merupakan laboratorium sederhana (laboratorium umum).

c) Penyuluhan Kesehatan Jiwa

Dalam pelaksanaannya, terdapat faktor-faktor yang mendukung terlaksananya kegiatan penyuluhan kesehatan seperti tersedianya dana, media, dan materi untuk digunakan dalam penyuluhan, inovasi dan kreativitas SDM sebagai promotor kesehatan yakni mengambil tema terkini untuk mencegah penyampaian materi penyuluhan yang monoton. Adanya antusiasme dari informan triangulasi yang merasakan keterbutuhan terkait penyuluhan kesehatan jiwa juga menjadi salah satu faktor pendukung terlaksananya kegiatan penyuluhan.

d) Penatalaksanaan Awal

Penatalaksanaan awal merupakan tahapan pemberian obat sesuai diagnosis yang didapatkan, baik penyakit kejiwaan maupun penyakit fisik lain sesuai kondisi pasien. Penatalaksaan awal dilakukan oleh petugas kesehatan kepada pasien dengan gangguan jiwa. Penatalaksanaan awal dilaksanakan setiap kali melakukan pemeriksaan.

e) Pengelolaan Rujukan Balik 
Pembenahan dalam kebijakan ini sebagai salah satu faktor pendukung bagi pasien untuk berobat rutin. Hal ini juga bisa mencegah timbulnya kasus baru gangguan jiwa akibat tidak tercovernya pengobatan pasien oleh karena banyaknya kesulitan pada sistem rujukan berjenjang.

- Variabel Output

a) Capaian Penyelidikan Epidemiologi (PE)

Meningkatnya pelayanan kesehatan jiwa terlihat dari meningkatnya persentase jumlah kunjungan baru penderita gangguan jiwa di Puskesmas. Berdasarkan data catatan petugas Puskesmas, jumlah kunjungan gangguan jiwa per Juni 2018 hanya sebanyak 19 pasien, dengan 4 di antaranya merupakan pasien yang sudah rutin melakukan kunjungan.

b) Capaian Fogging Fokus

Berdasarkan data penemuan kasus gangguan jiwa selama bulan Januari hingga bulan Juni 2018 di Puskesmas Bandarharjo, 1 dari 19 pasien dilakukan rujukan balik. Capaian pelayanan kesehatan jiwa pada orang dengan gangguan jiwa berat di wilayah kerja Puskesmas Bandarharjo per Juni 2018 adalah 94,7\%.

4. Kebutuhan Analisis Komunitas (Need Community Analysis)

- Bagi Puskesmas

a) Diharapkan adanya sikap proaktif dari Puskesmas untuk menjangkau masyarakat di seluruh wilayah kerjanya dengan cara memperbanyak kegiatan di luar Puskesmas.

b) Memberikan pemahaman kepada masyarakat melalui kegiatan sosialisasi program Upaya Kesehatan Jiwa serta melakukan follow-up terkait kegiatan sosialisasi tersebut.

- Bagi Masyarakat

Diharapkan masyarakat dapat mendukung dan berpartisipasi dalam pelaksanaan program Upaya Kesehatan Jiwa secara bersama-sama demi tercapainya tujuan program khususnya penurunan kasus di wilayah kerja Puskesmas Bandarharjo karena penyakit kesehatan jiwa tidak lepas dari pengaruh lingkungan yang ada di bawah kendali dari masyarakat itu sendiri. 


\section{Daftar Pustaka}

WHO.2018.Schizophrenia.http://www.who.int/mediacentre/fa ctsheets/fs397/en/Diakses 9 Juni 2018.

Kementerian Kesehatan Republik Indonesia. 2018. Laporan Kinerja Kementerian Kesehatan Tahun 2017.

Hermiati D, Harahap RM. 2018. Faktor Yang Berhubungan dengan Kasus Skizofrenia pada Pasien Rawat Inap RSKJ Soeprapto Provinsi Bengkulu.

Erlina, dkk. 2010. Determinan terhadap Timbulnya Skizofrenia pada Responden Rawat Jalan di Rumah Sakit Jiwa Prof. HB Saanin Padang Sumatera Barat.

Kementerian Kesehatan Republik Indonesia. 2016. Peraturan Menteri Kesehatan No.43 Tahun 2016 tentang Standar Pelayanan Minimal Bidang Kesehatan.

Kementerian Kesehatan Republik Indonesia. 2015. RAK Direktorat Bina Keswa Tahun 2015-2019.

Dinas Kesehatan Kota Semarang. 2017. Data Dasar Puskesmas Kota Semarang.

Dinas Kesehatan Kota Semarang. 2017. Profil Kesehatan Kota Semarang 2016.

Dinas Kesehatan Kota Semarang 2018. Data Gangguan Jiwa Tahun 2015-2017. 